\title{
Influence of Mastitis on Milk Yield in Holstein Cows
}

\author{
O. KOCAK \\ Istanbul University, Faculty of Veterinary Medicine, \\ Department of Animal Breeding and Husbandry, Istanbul, Turkey \\ Received April 12, 2006 \\ Accepted June 30, 2006
}

\begin{abstract}
Kocak O.: Influence of Mastitis on Milk Yield in Holstein Cows. Acta Vet. Brno 2006, 75: 507-513.

The objectives of the current study were to investigate the incidence of mastitis in a private dairy herd and the effect of the disease on the lactation milk yield (LMY), and on the daily average of the weekly milk yield (DMY). Only cows with no disease and cows with mastitis were included in the analyses. Mixed model procedures were used to analyse the DMY. Incidence of mastitis in the herd was $26.22 \%$. The incidences of first, second and third parity groups were $19.94 \%, 33.74 \%$ and $40.74 \%$, respectively. Daily milk losses because of mastitis varied between $0.76 \mathrm{~kg} / \mathrm{d}$ and 4.56 $\mathrm{kg} / \mathrm{d}$. The total milk loss was $600.87 \mathrm{~kg}$ for cows that became mastitic in the first six weeks of lactation and was $503.86 \mathrm{~kg}$ for cows that became mastitic after the sixth week of lactation. The milk losses of cows that contracted mastitis after the sixth week of lactation, began three weeks before the diagnosis. The mastitic cows failed to reach their healthy levels of milk yield during the rest of the lactation. The results indicate that weekly lactation records are useful in early detection of mastitis.
\end{abstract}

Mastitis, Holstein, parity, incidence, weekly intervals, disease detection

Mastitis is a common disease in dairy herds in many different countries, and causes economic loss in several ways (Gröhn et al. 2004). Costs associated with mastitis include lower production, discarded milk because of antibiotic therapy, labour, veterinary costs and treatments, and culling or death (Bartlett et al. 1991). Several studies have found that clinical mastitis has a detrimental effect on milk yield (B areille et al. 2003; B artlett et al. 1991; Firat 1993; Gröhn et al. 2004; Houben et al. 1993; Rajala et al. 1999; Shim et al. 2004).

Mastitis incidence of dairy herds reported in the literature varied between $9.7 \%$ and $36 \%$ (Hortet and Seegers 1998). The effect of clinical mastitis can differ, depending on the stage of lactation at which the disease occurs (Lucey and Rowlands 1984; Rajala and Gröhn 1998).

Some reviews about the relationship between clinical mastitis and milk yield reported variability between $3 \%$ to $8.1 \%$ for decrease in the milk yield per lactation for the effect of mastitis on milk production and estimates of milk yield loss ranged from 160 to $850 \mathrm{~kg} / \mathrm{cow}$ per lactation (Bartlett et al. 1991; Gröhn et al. 1995; Gröhn et al. 2004; Rajala et al. 1999; Smith et al. 2000).

A general problem with previous research on the effect of diseases on the milk yield is that the focus has been on the entire 305-d lactation curve. The 305-d milk yield cannot capture short-term fluctuations and drops in the milk yield. Cows with mastitis are often higher yielding cows, and they continue to yield more milk, even having contracted the disease, than do their healthy and generally lower-yielding herd mates (Gröhn et al. 1995). Therefore, daily and weekly milk yields should be taken into consideration when the effects of diseases on the milk yield are being investigated.

The objectives of the current study were to investigate the mastitis incidence in a private

\footnotetext{
Address for correspondence:

Dr. Omur KOCAK

Istanbul University, Faculty of Veterinary Medicine

Department of Animal Breeding and Husbandry, 34320 Avcilar Istanbul, TURKEY
}

Phone: 0.212.473 70 70-17334

Fax: 0.212.473 7241

e-mail: okocak@istanbul.edu.tr

http://www.vfu.cz/acta-vet/actavet.htm 
dairy herd and the effect of mastitis on the daily average of the weekly milk yield and the entire lactation milk yield.

\section{Materials and Methods}

This study was carried out in a private farm in the South-eastern Anatolia Region of Turkey. The South-eastern Anatolia Region located at the border of Syria and Iraq is the least developed region of the country. The cows were housed in semi-open free-stall barns and were milked three times daily in milking parlour. As the weather is very hot during the summertime, sprinklers and ventilators are used at the farm during the hot hours of the day. The farm has a capacity of 1,000 dairy cows and the movement of the cows, production status and the visits of the veterinarians are controlled by a computerized herd management program. In the milking parlour a carousel milking system for 50 cows is used. The data on the milk yield and the milk conductivity were transferred to computer automatically using Afimilk Meters (S.A.E. Afikim, Israel) and the data on the diagnosis and treatment practices were transferred to computer manually.

The animal material of this study was composed of Holstein cows that were milked between 2000 and 2003. Only cows with no diseases and cows with mastitis were included in the analyses. In this study diseases other than mastitis were not included in the analyses and the study was focused on the losses caused by mastitis only. Finally, edited dataset used for analyses comprised 1,171 lactation data from 915 Holstein cows.

The traits analysed were the daily averages of the weekly milk yields (DMY) and the lactation milk yield (LMY). The daily averages of the weekly milk yields (DMY) were calculated as follows: the milk weights were collected and recorded 3 times daily at each milking. They were then summed to give a daily value. Then, within each week of lactation, the daily values were summed and divided by 7 to give the mean daily milk yield for that particular week in lactation. In the calculation of the LMY of cows, which were milked for 285 - 305 days, linear interpolation was applied to estimate the 305-d lactation milk yield. On the other hand, when the lactation of a cow was longer than 305 days, only 305 days milk yield was used in the analyses.

Some cases of mastitis were identified by the milkers when cleaning the udders before milking. Others were detected by herdspersons examining cows whose electrical conductivity of milk increased by $>15 \%$ when compared with their previous 7 day rolling average and had a concurrent decrease in the milk yield. The farm veterinarians confirmed the diagnosis and began to treat mastitis. Intramammary antibiotics were used in mastitis cases which did not show systemic signs. In mastitic cows showing high body temperature or anorexia, farm veterinarians administered supporting treatment and systemic antibiotics according to the health status of the cow. The first mastitis records of the cows, which had a mastitis treatment for more than once, were taken into consideration. In the study, milk production weeks were separated into thirteen categories according to the periods in which mastitis was observed. These categories were:

Cows, which never had mastitis (healthy cows) ${ }^{1}$,

The period until $\geq 5$ weeks before mastitis was observed ${ }^{2}$,

The fourth week ${ }^{3}$, third week ${ }^{4}$, second week ${ }^{5}$ and first week ${ }^{6}$ before the diagnosis of mastitis,

The week, in which the diagnosis of mastitis was made ${ }^{7}$,

First week ${ }^{8}$, second week ${ }^{9}$, third week ${ }^{10}$, fourth week ${ }^{11}$ and fifth week ${ }^{12}$ after the diagnosis of mastitis, $\leq 6$ weeks after the diagnosis of mastitis ${ }^{13}$.

To compare incidences of mastitis for parity groups and lactation weeks, chi-square test was used. Mixed model procedures were used to analyse the DMY. In the analyses of the DMY, the following model was used:

DMY $_{\mathrm{ijklm}}=\mathrm{a}+$ cow $_{\mathrm{i}}+$ parity $_{\mathrm{j}}+$ week $_{\mathrm{k}}+$ mastitis $_{\mathrm{l}}+$ month $_{\mathrm{m}}+\left(\right.$ parity $\times$ week $_{\mathrm{jk}}+\epsilon_{\mathrm{ijklm}}$ where DMY is the $7-$ $\mathrm{d}$ average of the total daily milk production $(\mathrm{kg} / \mathrm{d})$,

$\mathrm{a}=$ intercept,

cow $_{\mathrm{i}}=$ random effect of cow $\mathrm{i}(\mathrm{i}=1,2, \ldots 915)$,

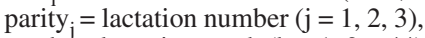

week $_{\mathrm{k}}=$ lactation week $(\mathrm{k}=1,2, \ldots 44)$,

mastitis $_{1}=$ mastitis category $(1,2, \ldots 13)$,

month $_{\mathrm{m}}=$ month in milk $(1,2, \ldots 12)$,

$(\text { parity } \times \text { week })_{\mathrm{jk}}=$ interaction between parity and week,

$\epsilon_{\mathrm{ijklm}}=$ random residual.

All terms other than cow ${ }_{\mathrm{i}}$ and $\epsilon_{\mathrm{ijklm}}$ were included in the model as fixed effects.

In the analyses of the DMY, the dataset was divided into two groups, according to the lactation week in which mastitis occurred. These groups were formed by the cows that had mastitis between calving and the $6^{\text {th }}$ week of lactation (MB- 6W), and the cows that suffered from mastitis after the $6^{\text {th }}$ week of lactation (MA-6W).

To compare the LMY of MB-6W, MA-6W and healthy cows (HC) for parity 1, 2 and 3, one-way ANOVA procedure was applied.

To compare the LMY of MB-6W, MA-6W and healthy cows (HC) for the entire dataset, least squares analysis which included the fixed effects of parity $(1,2,3)$, mastitis category and the random effect of cow was applied. SPSS 11.5 program package was used for the statistical analyses (SPSS 2004).

Rajala et al. (1999) reported that the problem in estimating the effect of mastitis in the early stage of lactation 
on the milk yield was that large proportion of the cows had mastitis so early that they did not have any milk measures taken before the onset of disease. On the other hand, the author reported that as mastitis cases were observed more frequently in cows with higher milk production, the comparison with healthy cows might be misleading and so as to calculate the milk losses, the milk yield of the mastitic cows should be compared with their milk yield before the onset of the disease. In the present study, the milk yield losses of mastitic cows were estimated by comparing the milk yield of cows in the mastitic period with their milk yield $\geq 5$ wk before the diagnosis.

\section{Results and Discussion}

Incidences of mastitis by parity and lactation weeks are presented in Tables 1 and 2, respectively. The effect of parity on mastitis incidence was significant $(p<0.05)$.

Table 1. Incidence of mastitis by parity

\begin{tabular}{|c|c|c|c|}
\hline Parity no & Number of cows & Number of mastitic cows & Incidence (\%) \\
\hline 1 & 707 & 141 & $19.94^{\mathrm{a}}$ \\
2 & 329 & 111 & $33.74^{\mathrm{b}}$ \\
3 & 135 & 55 & $40.74^{\mathrm{b}}$ \\
\hline All & 1171 & 307 & 26.22 \\
\hline
\end{tabular}

a, b $p<0.05$

Table 2. Incidence of mastitis by lactation weeks

\begin{tabular}{|c|c|c|c|}
\hline Weeks of lactation & No. of mastitic cows & \multicolumn{2}{|c|}{ Percentage of mastitis \% } \\
\cline { 2 - 3 } & & Within all cows & Within mastitic cows \\
\hline $1-4$ & 65 & $5.55^{\mathrm{a}}$ & $21.17^{\mathrm{a}}$ \\
$5-8$ & 36 & $3.07^{\mathrm{bc}}$ & $11.73^{\mathrm{bc}}$ \\
$9-12$ & 29 & $2.48^{\mathrm{bc}}$ & $9.45^{\mathrm{bcd}}$ \\
$13-16$ & 37 & $3.16^{\mathrm{b}}$ & $12.05^{\mathrm{b}}$ \\
$17-20$ & 30 & $2.56^{\mathrm{bcd}}$ & $9.77^{\mathrm{bcd}}$ \\
$21-24$ & 19 & $1.62^{\mathrm{def}}$ & $6.19^{\mathrm{def}}$ \\
$25-28$ & 22 & $1.88^{\mathrm{cdef}}$ & $7.17^{\mathrm{cde}}$ \\
$29-32$ & 19 & $1.62^{\text {def }}$ & $6.19^{\text {def }}$ \\
$33-36$ & 24 & $2.05^{\mathrm{bcde}}$ & $7.82^{\mathrm{bcde}}$ \\
$37-40$ & 15 & $1.28^{\text {ef }}$ & $4.89^{\mathrm{ef}}$ \\
$41-44$ & 11 & $0.94^{\mathrm{f}}$ & $3.58^{\mathrm{f}}$ \\
\hline Total & 307 & 26.22 & 100.00 \\
\hline
\end{tabular}

a, b, c, d, e, f $p<0.05$

Mastitis incidence of the herd was $26.22 \%$. This incidence was higher than the results of Bartlett et al. (1991), Gröhn et al. (1995) and Rajala and Gröhn (1998) as $9.7-18.6 \%$, similar to the results of B arkema et al. (1998) and Lucey and Rowlands (1984) as 24.0 - 26.0\%, and lower than the result of Firat (1993) as 35.8\%. Parity 1 had significantly $(p<0.05)$ lower incidence of mastitis compared with parity 2 and parity 3 . Similar to the current study, for parity 1 , parity 2 and parity 3 the results were $6.6 \%, 9.0 \%$ and $14.2 \%$ in the study by Houben et al. (1993), 17\%, 22\% and $24 \%$ in the study by Lucey and Rowlands (1984) and $12.1 \%, 14.3 \%$ and $14.9 \%$ in the study by Rajala et al. (1999).

The effect of the lactation week on mastitis incidence was significant $(p<0.05)$. The highest numbers of mastitic events were in the first four weeks and $21.17 \%$ of the total mastitic events were in this period.

The incidence of mastitis in the initial period of lactation was higher than the incidence in other periods, and this result was in agreement with the reports of Barkema et al. (1998) as $30 \%$ in the first 14 days of lactation, Houben et al. (1993) as 33\% for parity 1, 23\% for 
parity 2 and $20 \%$ for parity 3 in the first month and Lucey et al. (1986) as $16.1 \%$ before the peak yield period. The authors explained the rise in mastitis incidence in the beginning of lactation by the positive relationship between the high milk yield and mastitis. In addition, some researchers reported that mastitis risk might increase with the rise in the milk yield (Bartlett et al. 1991; Gröhn et al. 1995; Smith et al. 2000).

The least squares means of the DMY by occurrence of mastitis between calving and $6^{\text {th }}$ week of lactation (MB-6W) are presented in Table 3. The effect of the week of mastitis on the DMY was significant $(p<0.001)$. There was a significant decrease in the milk yield one week before the diagnosis, in the diagnosis week and during the weeks after the diagnosis. In this study, the milk losses in the mastitic cows, which had mastitis between calving and the $6^{\text {th }}$ week of lactation were $3.69 \mathrm{~kg} / \mathrm{d}$ one week before the diagnosis, $4.71 \mathrm{~kg} / \mathrm{d}$ in the diagnosis week, $2.67 \mathrm{~kg} / \mathrm{d}$ one week, $2.62 \mathrm{~kg} / \mathrm{d}$ two weeks and $2.45 \mathrm{~kg} / \mathrm{d}$ three weeks after the diagnosis.

Table 3. Least-Squares means (LSM) of the daily averages of weekly milk yields (DMY) by mastitis category for cows, which had mastitis between calving and $6^{\text {th }}$ week of lactation (MB-6W) (kg)

\begin{tabular}{|c|c|c|}
\hline Mastitis Category & LSM & SE \\
\hline Healthy cows & $30.54^{\mathrm{a}}$ & 0.040 \\
2 wk before & $30.69^{\mathrm{a}}$ & 0.506 \\
1 wk before & $27.44^{\mathrm{de}}$ & 0.412 \\
Diagnosis week & $26.42^{\mathrm{e}}$ & 0.367 \\
1 wk after & $28.46^{\mathrm{cd}}$ & 0.367 \\
2 wk after & $28.51^{\mathrm{c}}$ & 0.367 \\
3 wk after & $28.68^{\mathrm{bc}}$ & 0.367 \\
4 wk after & $29.04^{\mathrm{bc}}$ & 0.367 \\
5 wk after & $29.35^{\mathrm{bc}}$ & 0.367 \\
$\geq 6$ wk after & $29.33^{\mathrm{b}}$ & 0.121 \\
\hline
\end{tabular}

a, b, c, d, e $p<0.001$

Table 4. Least-Squares means (LSM) of the daily averages of weekly milk yields (DMY) by mastitis category for cows, which had mastitis after $6^{\text {th }}$ week of lactation (MA-6W) $(\mathrm{kg})$

\begin{tabular}{|c|c|c|}
\hline Mastitis Category & LSM & SE \\
\hline Healthy cows & $30.64^{\mathrm{b}}$ & 0.039 \\
25 wk before & $31.13^{\mathrm{a}}$ & 0.084 \\
4 wk before & $30.73^{\mathrm{ab}}$ & 0.229 \\
3 wk before & $30.37^{\mathrm{bc}}$ & 0.229 \\
2 wk before & $29.71^{\mathrm{de}}$ & 0.229 \\
1 wk before & $26.57^{\mathrm{h}}$ & 0.229 \\
Diagnosis week & $27.40^{\mathrm{g}}$ & 0.229 \\
1 wk after & $28.99^{\mathrm{f}}$ & 0.232 \\
2 wk after & $29.21^{\mathrm{ef}}$ & 0.233 \\
3 wk after & $29.40^{\mathrm{def}}$ & 0.234 \\
4 wk after & $29.73^{\mathrm{de}}$ & 0.235 \\
5 wk after & $29.85^{\mathrm{cd}}$ & 0.237 \\
$\geq 6$ wk after & $29.45^{\mathrm{de}}$ & 0.084 \\
\hline
\end{tabular}

a, b, c, d, e, f, g, h $p<0.001$

The least squares means of the DMY by occurrence of mastitis after the $6^{\text {th }}$ week of lactation (MA-6W) are presented in Table 4. The effect of the week of mastitis on the DMY was significant $(p<0.001)$. There were significant decreases in the milk yield three weeks, 
two weeks and one week before, and during the weeks after the diagnosis. The milk losses in the mastitic cows, which became mastitic after the $6^{\text {th }}$ week of lactation, began three weeks before the diagnosis. Milk losses three weeks, two weeks and one week before the diagnosis, in the diagnosis week, one, two and three weeks after the diagnosis were 0.76 $\mathrm{kg} / \mathrm{d}, 1.42 \mathrm{~kg} / \mathrm{d}, 4.56 \mathrm{~kg} / \mathrm{d}, 3.73 \mathrm{~kg} / \mathrm{d}, 2.14 \mathrm{~kg} / \mathrm{d}, 1.92 \mathrm{~kg} / \mathrm{d}, 1.73 \mathrm{~kg} / \mathrm{d}$, respectively.

For the period $\geq 5 \mathrm{wk}$ before the diagnosis, the mastitic cows actually produced 0.49 $\mathrm{kg} / \mathrm{d}$ more milk than their healthy herd mates did.

Losses in the milk yield before the clinical diagnosis of mastitis in dairy cows have been previously reported (Bartlett et al. 1991; Gröhn et al. 2004; Lucey et al. 1986; Rajala et al. 1999). This loss could be an indication of subclinical infection before the signs start or the early stages of clinical mastitis could be undetectable to the herdsperson ( Gröhn et al. 2004).

Rajala et al. (1999) reported that the DMY of mastitic cows one week before the diagnosis significantly decreased for parity $3(2.4 \mathrm{~kg} / \mathrm{d})$ and parity $4(2.2 \mathrm{~kg} / \mathrm{d})$ but not for parity $1(1 \mathrm{~kg} / \mathrm{d})$ and $2(0.8 \mathrm{~kg} / \mathrm{d})$. In contrast with the current study, Luc ey et al. (1986) did not find a significant decrease in the milk yield during the pre-mastitis period for the cows that became mastitic in the period before the peak yield.

Similarly to the current study, Rajala et al. (1999) reported a significant decrease in the DMY of mastitic cows 28 days before the diagnosis for parity $1(0.8 \mathrm{~kg} / \mathrm{d}), 2(0.8 \mathrm{~kg} / \mathrm{d}), 3$ $(0.9 \mathrm{~kg} / \mathrm{d})$ and 14 days before the diagnosis for parity $4(0.7 \mathrm{~kg} / \mathrm{d})$. Luc ey et al. (1986) also reported a $0.8 \mathrm{~kg} / \mathrm{d}$ loss in the milk yield in the pre-diagnosis period for the cows that became mastitic in the period after the peak yield.

After mastitis, the cows were not able to reach their before-mastitis milk yield during the rest of the lactation; some authors' results are in agreement with the results of the present study (Gröhn et al. 2004; Rajala et al. 1999).

The total loss was $600.87 \mathrm{~kg}$ for the cows that became mastitic in the first six weeks of lactation (the total milk loss was calculated assuming a 305-d lactation and the occurrence of mastitis on $\mathrm{d} 7 \mathrm{after}$ calving) and was $503.86 \mathrm{~kg}$ in the cows that became mastitic after the sixth week of lactation (the total loss was calculated assuming a 305-d lactation and the occurrence of mastitis on d 43 after calving).

The lactation milk losses found in the current study were higher than the reports of Bartlett et al. (1999), Bareille et al. (2003), Fetrow et al. (1991), Firat (1993), Shim et al. (2004), similar to the reports of Houben et al. (1993), Wils on et al. (1997), Rajala et al. (1999) and lower than the reports of Lescourret and Coulon (1994) and Gröhn et al. (2004).

Lactation milk yields of cows that had mastitis between calving and the $6^{\text {th }}$ week of lactation (MB-6W), cows that had mastitis after the $6^{\text {th }}$ week of lactation (MA-6W) and healthy cows (HC) by parity groups are presented in Table 5. The differences between MB$6 \mathrm{~W}, \mathrm{MA}-6 \mathrm{~W}$ and HC groups for the LMY of parity 1 and 2 were not significant $(p>0.05)$.

Table 5. Lactation milk yields (LMY) of mastitic cows and healthy cows by parity (kg)

\begin{tabular}{|c|c|c|c|c|c|c|c|c|c|}
\hline \multirow{2}{*}{ Parity } & \multicolumn{3}{|c|}{ HC } & \multicolumn{3}{|c|}{ MB-6W } & \multicolumn{3}{c|}{ MA-6W } \\
\cline { 2 - 9 } & $\mathrm{n}$ & LMY & SE & $\mathrm{n}$ & LMY & SE & $\mathrm{n}$ & LMY & SE \\
\hline 1 & 566 & 8131.2 & 54.56 & 41 & 8116.4 & 202.72 & 100 & 8307.3 & 129.81 \\
2 & 218 & 9549.6 & 98.97 & 24 & 9707.4 & 298.29 & 87 & 9488.6 & 156.67 \\
3 & 80 & $10250.3^{\mathrm{a}}$ & 161.61 & 18 & $9368.5^{\mathrm{b}}$ & 340.70 & 37 & $9842.5^{\mathrm{a}}$ & 237.63 \\
All & 864 & $9400.6^{\mathrm{a}}$ & 65.18 & 83 & $8816.9^{\mathrm{b}}$ & 183.49 & 224 & $9302.0^{\mathrm{a}}$ & 107.06 \\
\hline
\end{tabular}

a, b $p<0.05$

* HC: Healthy cows, MB-6W: occurrence of mastitis between calving and $6^{\text {th }}$ week of lactation, MA-6W: occurrence of mastitis after $6^{\text {th }}$ week of lactation. 
However, the differences between MB-6W with HC and MA6W were significant for parity 3 and the entire dataset $(p<0.05)$.

When the HC, MB-6W and MA-6W lactation milk productions by parity were compared, it was seen that the first and second parity cows compensated for the effects of mastitis as they had higher milk yields than the healthy cows and the differences were not significant. However, in parity three, the milk losses of the cows that had mastitis in the first six weeks of lactation, were at a significant level and, although the cows with mastitis usually have high milk yields, they were not able compensate for the loss. Rajala and Gröhn (1998) reported that the yield of the oldest cows seemed to be most affected when mastitis occurred before the peak and found the milk yield losses to be $109.9 \mathrm{~kg}(1.8 \%)$ for parity $1,219.6 \mathrm{~kg}$ $(3.1 \%)$ for parity 2 and $387.3 \mathrm{~kg}(5.2 \%)$ for parity 3 . These results are in agreement with the results of the current study.

The cows that had mastitis, could not reach their milk productions before the illness. The incidence of mastitis was higher in the initial periods of lactation and particularly among the cows with a higher milk yield. Consequently, it was determined that additional management programs should be applied in the initial periods of lactation and particularly to the cows with a higher milk yield.

\section{Vliv mastitidy na nádoj u holštýnských krav}

Cílem této studie bylo zjistit incidenci mastitidy v soukromém stádu dojnic a vliv mastitidy na celkový nádoj během laktace a na denní průměr týdenního nádoje (DN). Do analýz byly zahrnuty pouze dojnice zdravé a dojnice s mastitidou. K analýze DN bylo použito smíšeného modelu ANOVA. Incidence mastitidy u stáda byla 26,22 \%. Incidence mastitidy u skupin první, druhé a třetí parity byly 19,94 \%, 33,74 \% a 40,74 \%. Denní ztráty způsobené mastitidou se pohybovaly mezi $0,76 \mathrm{~kg} / \mathrm{d}$ a $4,56 \mathrm{~kg} / \mathrm{d}$. Celková ztráta byla $600,87 \mathrm{~kg}$ u dojnic, které onemocněly mastitidou během prvních šesti týdnů laktace a 503,86 kg u krav, které onemocněly po šestém týdnu laktace. Ztráty mléka u dojnic, které dostaly mastitidu po šestém týdnu laktace, začaly tři týdny před diagnózou. Dojnice s mastitidou nebyly po zbytek laktace schopné dosáhnout své zdravé úrovně nádoje.

\section{References}

BAREILLE N, BEAUDEAU F, BILLON S, ROBERT A, FAVERDIN P 2003: Effects of health disorders on feed intake and milk production in dairy cows. Livest Prod Sci 83: 53-62

BARKEMA HW, SCHUKKEN YH, LAM TJGM, BEIBOER ML, WILMILK H, BENEDICTUS G, BRAND A 1998: Incidence of clinical mastitis in dairy herds grouped in three categories by bulk milk somatic cell counts. J Dairy Sci 81: 411-419

BARTLETT PC, VAN WIJK J, WILSON DJ, GREEN CD, MILLER GY, MAJEWSKI GA, HEIDER LE 1991: Temporal patterns of lost milk production following clinical mastitis in large Michigan Holstein herd. J Dairy Sci 74: 1561-1572

FETROW J, MANN D, BUTCHER K, MCDANIEL B 1991: Production losses from mastitis: carry-over from the previous lactation. J Dairy Sci 74: 833-839

FIRAT MZ 1993: An investigation into the effects of clinical mastitis on milk yield in dairy cows. Livest Prod Sci 36: $311-321$

GRÖHN YT, EICKER SW, HERTL JA 1995: The association between previous 305-day milk yield and disease in New York state dairy cows. J Dairy Sci 78: 1693-1702

GRÖHN YT, WILSON DJ, GONZALEZ RN, HERTL JA, SCHULTE H, BENNETT G, SCHUKKEN YH 2004: Effect of pathogen-specific clinical mastitis on milk yield in dairy cows. J Dairy Sci 87: 3358-3374

HORTET P, SEEGERS H 1998: Loss in milk yield and related composition changes resulting from clinical mastitis in dairy cows. Prev Vet Med 37: 1-20

HOUBEN EHP, DIJKHUIZEN AA, VAN ARENDONK JAM, HUIRNE RBM 1993: Short- and long-term production losses and repeatability of clinical mastitis in dairy cattle. J Dairy Sci 76: 2561-2578

LESCOURRET F, COULON JB 1994: Modelling the impact of mastitis on milk production by dairy cows. J Dairy Sci 77: 2289-2301

LUCEY S, ROWLANDS GJ 1984: The association between clinical mastitis and milk yield in dairy cows. Anim Prod 39: 165-175 
LUCEY S, ROWLANDS GJ, RUSSELL AM 1986: Short-term associations between disease and milk yield of dairy cows. J Dairy Res 53: 7-15

RAJALA PJ, GRÖHN YT 1998: Disease occurrence and risk factors analysis in Finnish Ayrshire cows. Acta Vet Scand $39: 1-13$

RAJALA PJ, GRÖHN YT, MCCULLOCH CE, GUARD CL 1999: Effects of clinical mastitis on milk yield in dairy cows. J Dairy Sci 82: 1213-1220

SHIM HE, SHANKS RD, MORIN DE 2004: Milk loss and treatment costs associated with two treatment protocols for clinical mastitis in dairy cows. J Dairy Sci 87: 2702-2708

SMITH JW, ELY LO, CHAPA MA 2000: Effect of region, herd size, and milk production on reasons cows leave the herd. J Dairy Sci 83: 2980-2987

SPSS 2004:SPSS for windows advanced statistics release 11.5.

WILSON DJ, GONZALEZ RN, DAS HH 1997: Bovine mastitis pathogens in New York and Pennsylvania: Prevalence and effects on somatic cell count and milk production. J Dairy Sci 80: 2592-2598 